\title{
Origin, historical and landscape evolution of the Expedicionários Square, São João Del Rei-MG ${ }^{(1)}$
}

\author{
ALINE SILVA MUNDIM(2), PATRÍCIA DUARTE DE OLIVEIRA PAIVA(2), RAFAEL DE BRITO SOUZA(2), FRANCILENE DE \\ LOURDES BONIFÁCIO(2) and SCHIRLEY FÁTIMA NOGUEIRA DA SILVA CAVALCANTE ALVES ${ }^{(3)}$
}

\begin{abstract}
The squares built in Brazil from the eighteenth and nineteenth centuries, especially those located along the Royal Road, have characteristic traces and species, and generally had their origin near or as part of a church. The city of São João Del Rei-MG emerged in this region, specifically in the Old Path of the Royal Road [Estrada Real], from gold exploration in the eighteenth century. Thus, this study aimed at the historical and landscape survey of the Expedicionários Square, one of the squares located in the historic center of the city of São João Del Rei-MG. The methodology used consisted of an inventive analysis, associated with a subjective analysis, which allowed the study of the evolution of the area, based on the analysis of morphological changes that occurred in the square by different interventions. The value and uses by the population were also considered, at the different evolution periods of the place. Based on the information collected, modifications both in the structure and in the toponymy of this square were observed. The layout of the square has characteristics of an eclectic style, with irregular stones in its interior and beds with geometric paths, typical of the urbanization of the late nineteenth and early twentieth century. The plants used consist mainly of ornamental trees and shrubs, without an apparent logical planning. The importance of the square is related to its use and frequency by the population, besides the cultural and historical value of the place, since it houses the Legalidade Fountain, a landmark in the city of São João Del Rei (MG).
\end{abstract}

Keywords: Historical gardens, Royal Road, toponymy, historical squares.

\section{RESUMO}

Origem, evolução histórica e paisagística da Praça dos Expedicionários, São João Del Rei-MG

As praças construídas no Brasil a partir dos séculos XVIII e XIX, sobretudo aquelas localizadas ao longo da Estrada Real, possuem traçados e espécies características e geralmente, tiveram sua origem próximo ou como parte de uma igreja. A cidade de São João Del Rei-MG emergiu nesta região, especificamente no Caminho Velho da Estrada Real, a partir da exploração de ouro no século XVIII. Assim, este estudo teve como objetivo o levantamento histórico e paisagístico da Praça dos Expedicionários, uma das praças localizadas no centro histórico da cidade de São João Del Rei-MG. A metodologia utilizada consistiu da análise inventiva associada à análise subjetiva, que permitiram o estudo da evolução da área, baseando-se na análise de alterações morfológicas ocorridas na praça pelas diferentes intervenções. Também o valor e usos pela população foram considerados, nas diferentes épocas da evolução da praça. Baseando-se nas informações coletadas, observaram-se modificações tanto na estrutura quando na toponímia dessa praça. O traçado da praça tem características de estilo eclético, com pedras irregulares no seu interior e canteiros com caminhos geométricos, típicos da urbanização do final do século XIX e início do século XX. As plantas utilizadas consistem principalmente de árvores e arbustos ornamentais, sem um aparente planejamento lógico. A importância da praça está relacionada ao seu uso e frequência pela população, e também há o valor cultural e histórico do local, por abrigar o Chafariz da Legalidade, um marco da cidade São João Del-Rei (MG).

Palavras-chave: Jardins históricos, Estrada Real, toponímia, praças históricas.

\section{INTRODUCTION}

The discovery of gold in abundance at the end of the seventeenth century was central to colonial evolution. The exploitation of the immense riches led to the settlement of Brazil and attracted the attention of other peoples to the largest center of gold production until then, which had a decisive influence in the elaboration of the capitalist economy in the region (SODRÉ and SCHENDEL, 1979). Gold was incorporated into enterprises and encouraged the cattle market and troops in the interior of Brazil, making Rio de Janeiro the national capital (SIMONSEM, 2005).

DOI: http://dx.doi.org/10.14295/oh.v23i4.1118

(1) Received on 12/08/2017 and accepted on 18/12/2017

(2) Universidade Federal de Lavras (UFL), Departamento de Agricultura, Lavras-MG, Brazil. *Corresponding author: alinemundim@hotmail.com

(3) Centro Universitário de Lavras, Lavras-MG, Brazil

Licensed by CC BY 4.0 
The movement of both gold and cattle was carried out in roads built in the interior of Brazil on the occasion of flag intensification, from the second half of the sixteenth century, which resulted in the formation of several cities and the expansion of agricultural activities (CALAES and OLIVEIRA, 2009). Thus, at the beginning of the eighteenth century, there were two official routes leading to Minas Gerais, as well as many others for the flow of gold and diamonds. In order to avoid diversion and evasion, it was determined that all the gold and diamonds mined in Minas Gerais would be flowed out only by official roads, which began to be watched and became known as Royal Road (CALAES and OLIVEIRA, 2009).

Due to its great importance, several villages, cities and towns arose along the Royal Road. The scenario of the socalled historical cities is formed by cities that had their apex in the eighteenth century. In addition, this region of Minas Gerais has the characteristic of having been predominantly urbanized before being rural (MARTINS, 1992).

In Colonial Brazil, the Jesuits used the gardens for religious purposes. The plants were used as food and medicine, in addition to rituals. In the nineteenth century, with urbanization, landscaped spaces were intensively found in squares, parks and public gardens. At the end of the nineteenth century and the first decades of the twentieth century, during the belle époque, there was a strong concern about the hygiene of cities: they should be beautiful, with clean, well-marked and wooded streets (DELPHIM, 2005).

Thus, the study of historical gardens reveals their trajectories to the public knowledge and allows their insertion in the contemporary cultural context (ALVES, 2016). It is important to emphasize that knowledge of the history of gardens is fundamental for their protective actions, since they enrich the value of their evolution, and largely fulfill the anthropic survey necessary for cultural heritage management. It is considered as a historic garden man-made sites and landscapes, created in the form of botanical gardens (common in Europe and prominent in Brazil for the Botanical Garden of Rio de Janeiro), squares, parks, public walks, among others. These are references to the understanding of the relationship between urban man and nature (CARTA DE JUIZ DE FORA, 2010).

Therefore, the purpose of this study was to analyze the historical and landscape evolution of the Expedicionários Square, located in the historical center of São João delRei, from its construction in the nineteenth century to the present day.

\section{MATERIAL AND METHODS}

The research carried out to identify the origin and historical evolution of the Expedicionários Square, located in the city of São João del-Rei (MG), concentrated in the period between 1840, which corresponds to the date of the first documentary record found on the square, until the present days, in 2017. The methodology used was a combination of the inventive analysis presented by Lassus (1994), with the subjective analysis described by Luginbuhl (2006), and added by the considerations made by Delphim (2005 for historical gardens conservation.

By the inventive analysis (LASSUS, 1994), it was possible to identify physical evolution processes and the practices developed in the place through the interpretation of natural, patrimonial and social data. These results in identifying what would be most appropriate in the relationship between the place and its social practices. Thus, through interviews directed to citizens and historians who knew and/or attend the place, the uses and impressions about the square were identified at different times (interviewees were invited to report impressions of past times about the area). The interviewing approach was informal, without the application of questionnaires, in order to allow interviewees to freely report their experiences. Questions such as "What was the square like in the past?", "What drew your attention the most?", "What did people do there?", "What were the plants and beds like?", "Would you like to tell an interesting fact?", were asked. Therefore, it was possible to deepen the investigations by combining the life histories of the interviewees with the socio-historical context of the studied sites.

Documents were also consulted to identify the interventions that took place and the registration, especially of nomenclature, besides changes in its structure.

The subjective analysis (LUGINBUHL, 2006) does not lead to a measurable evaluation, but reveals aesthetic or symbolic values. This method is based on the hypothesis that landscapes and their representations point to values attributed by the population, artists or writers that portray with more sensitivity the aesthetic or symbolic attributes in their works. Thus, all existing iconographic records of this square were raised, highlighting photographs and postcards. No paintings were identified. Texts, especially those published in newspapers, were also searched.

Delphim (2005) considers the intrinsic values of a cultural good, which refer to the good from the physical point of view. They include the environment, material, conservation, design and location. Any space undergoes transformation or deterioration, both due to natural wear and use. The sum of these different modifications becomes part of the historical character. In addition, cultural goods may have other values, extrinsic, such as cultural, identity, technical or artistic, besides originality, historical, social, economic, functional, educational and political attributes.

The bibliographical and iconographic surveys of São João del-Rei and the Expedicionários Square were carried out in the Municipal Museum of São João del-Rei, the Municipal Library, the National Institute of Historic and Artistic Heritage (Instituto do Patrimônio Histórico e Artístico Nacional, IPHAN), the Historic and Geographic Institute (Instituto Histórico e Geográfico, $\mathrm{IHG)}$ and in the Secretary of Culture, with access to documents in relation to the works of the Growth Acceleration Program (Programa de Aceleração do Crescimento, PAC) and the Works Department in the City Hall. 
In the final part of the research, surveys of urban and botanical furniture of the square were carried out, with identification of the species currently present in the place, considering its state of conservation and a broad photographic record of the current situation.

With the addition of all information, it was possible to reconstruct the history of the Expedicionários Square, making a chronology of the transformations that occurred, correlating with the evolution of the city of São João del-Rei.

\section{RESULTS AND DISCUSSION}

\section{São João del-Rei - origin}

The Arraial do Rio das Mortes began to exist from 1684 when Tomé Portes del-Rei settled on the banks of River "das Mortes". The exploitation of gold mines attracted numerous inhabitants to the territory of São João del-Rei (BURTON, 2001; COSTA et al., 2005; SAINT-HILAIRE, 1941).

The gold, abundant and easy to explore on the hillslopes that surrounded the village, guided the paths between the village and the exploration areas. From the mountains, the road led down to the Lenheiro Stream, whose banks were directed mainly towards River "das Mortes"; its port served as a passage for crossing with the tax payment known as Porto Real da Passagem (MALDOS, 2000).

For a long time, São João Del Rei was named Arraial of River "das Mortes" and, on December 18, 1713, the Arraial was elevated to village under the name of Vila de São João del-Rei, in honor of King João V, regent at the time. This was the first step in the organization of an administrative policy, with guidelines in the process of urban formation (MALDOS, 2000).

São João del-Rei is one of the largest and most important historic cities in Minas Gerais. The evolution of the mining camp to an important commercial pole in the Campo das Vertentes region was responsible for its peculiar characteristic that mixes baroque architectural styles with the modern style.

\section{Emergence of the Expedicionários Square}

The area where the square is located has great historical value, since its construction was in the 18th century and it is situated at the junction of the main streets of the old village (Figure 1).

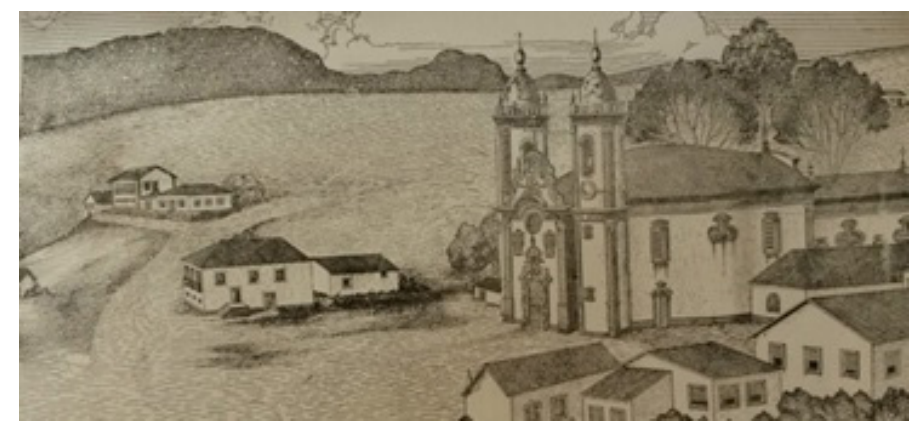

Figure 1. Region where the square was built. Source: IPHAN (1800).

The current Expedicionários Square appeared in the middle 1830s, and it was known as Intendência Square at that time; it has undergone many changes from its emergence until the present day.

\section{Evolution of the square}

The first photographic record found (Figure 2) dates from approximately 1910, when the square was part of the 51 st Battalion of hunters and the 2nd Battalion of the 11th Infantry Regiment, and was known as Batallion Garden.

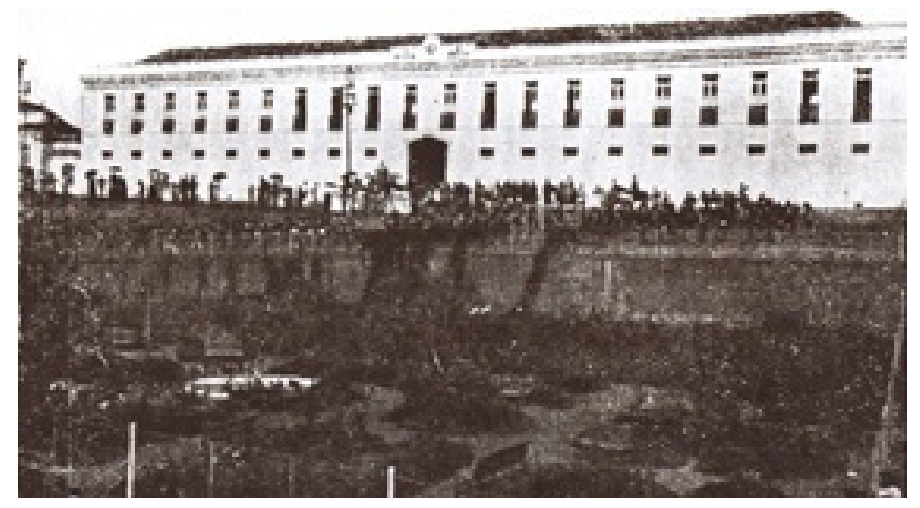

Figure 2. Batallion Garden.

Source: IPHAN (1901) 
In Figure 2, it is possible to observe the building of the Battalion and the landscaping that the square presented. It is also observed that the whole area was surrounded with a screen. Its layout consisted of several small beds of different shapes and sizes, had benches and a central circular structure, seeming to be a fountain.
In a photograph of 1915 (Figure 3), it is possible to notice differences in the structure and maintenance of the square. The species appear to be slightly more developed, both in the square and the front of the building. It is possible to observe some shrubs pruned in a rounded shape and cultivated in an aligned way along the access ramp to the Battalion building, besides trees of medium size parallel to the building, which no longer exist.

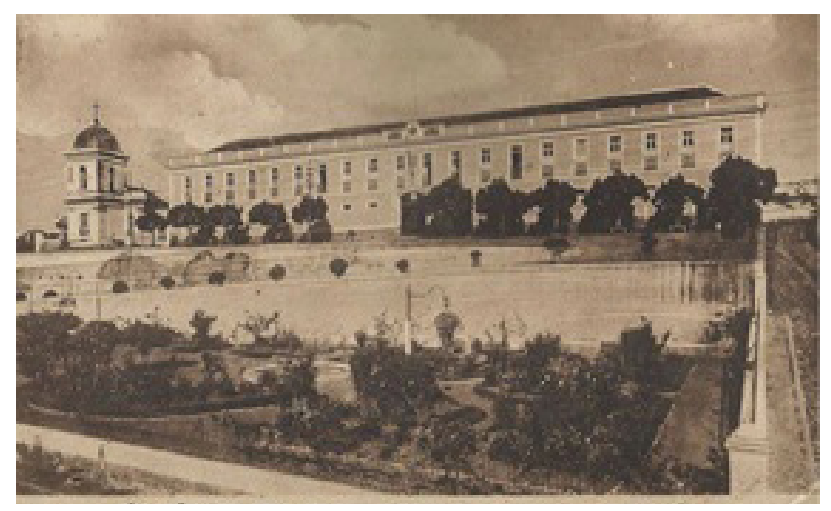

Figure 3. Batallion Garden.

Source: Pedro Paulo Viegas’ Personal File (1915).

Over time, the landscaping of the square was modified, which made the layout simpler and reduced the number of plants; the presence of some shrubs is verified. By size, it is inferred that they were implanted at the time of this photo, in the 1930s (Figure 4).

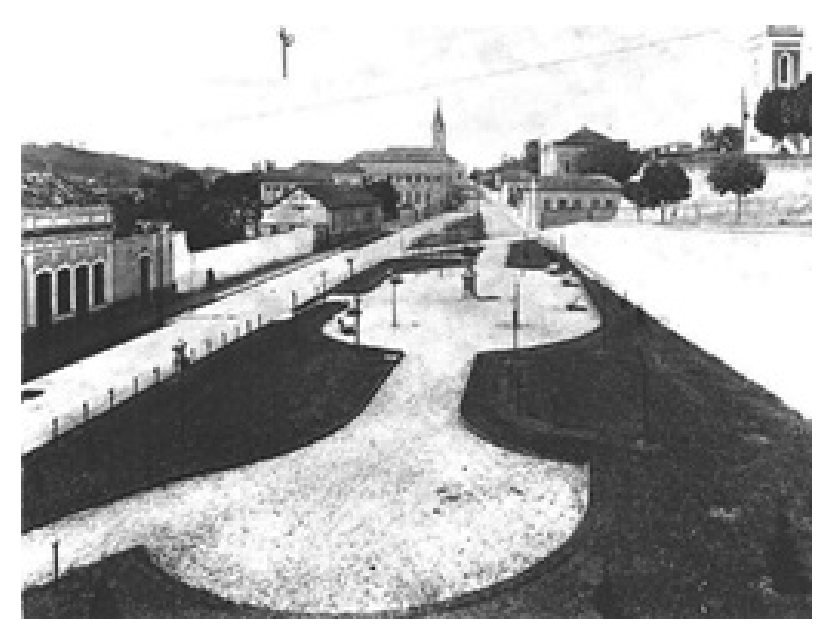

Figure 4. First major renovation at the Expedicionários Square in 1930. Source: IPHAN.

The beds that initially existed (Figure 3) were modified: they were joined, forming larger beds. The paths are geometric and the lush beds with flowering shrubs were replaced by a simple vegetation consisting of some shrubs and the laying of a lawn in the extension of the beds.
It is also possible to identify benches distributed in the central part of the square (Figure 5). There was a free space in the center of which was a vase arranged on top of a cement column, reminding the Italian style. The screens that surrounded the garden were replaced by a low and discreet enclosure, delimiting the front of the square. The access to the garden that seemed to be controlled, becomes free. 


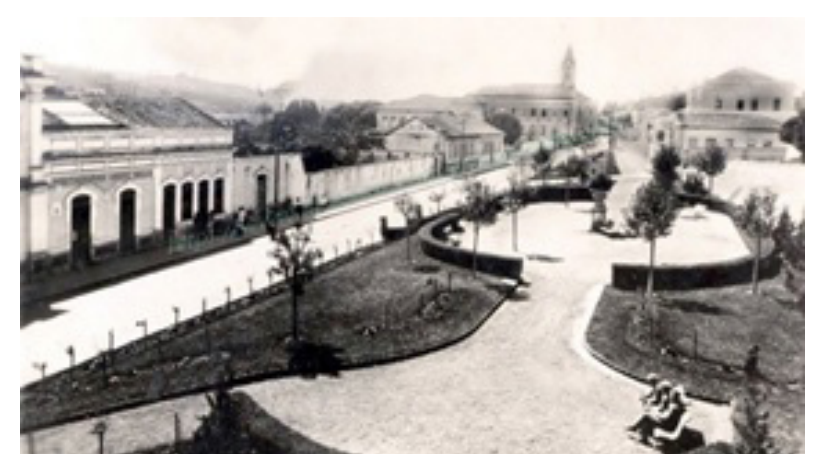

Figure 5. Evolution of the Expedicionários Square.

Source: IPHAN.

After a few years, trees and shrubs, whose species are not identifiable, are larger and more showy (Figure 5). The grass also grew and the environment has stakes, marking the border outline of the square. In the inner part of the square, it is observed that the hedge is already well developed and formed, bypassing the rounded design of the beds; in an interview, a former attendant reported to be a cypress (Cupressus sp.).

\section{Toponymy}

Toponymy is the area of investigation that is based on the idea that the appointment of a place does not occur in an unreasonable way, revealing important historical information and events. Through toponymy, it is possible to analyze the relationship between man and the names of the space in which they are inserted, obtaining knowledge of historical-cultural aspects of a people (ARTEN, 2010; CARVALHO, 2013).

Over time, the square had several denominations. The first document that records the name of the square dates from 1840, and cites it as Intendência Square, in reference to the building where the Intendência and Gold Casting House ${ }^{(4)}$ worked, located in the pavilion above the square.

With the extinction of the Intendência and Gold Casting House, the building started to house the Duval School (Colégio Duval) and, from 1859, the square became known as Colégio Square (GUIMARÃES, 1994).
In 1897, it received the name of República Square, due to the political campaign at the time in relation to the conflict "War of Canudos"(5). In 1928, with the visit of the family of the president of the state of Minas Gerais, Antônio Carlos Ribeiro de Andrada, that same year, it came to be called the Andradas Square, as a tribute.

And finally, in 1960, it was named Expedicionários Square in honor of the combatants who participated in World War II. This name remains to this day.

With all these changes, there is a loss of the identity of the square in relation to its beginnings. Some historical moments fall into oblivion of the population and are not always disclosed, considering their importance for different generations.

Legalidade Fountain and the Monumento aos Expedicionários

The Legalidade Fountain is inserted in the relationship of goods registered by the National Institute of Historic and Artistic Heritage since 1938. The structure was initially built in Largo do Tamandaré in São João del-Rei, in 1834, in commemoration of the fact that Vila de São João del-Rei was the capital of the Province of Minas Gerais in 1833. The water supplying it came from the aqueduct (Figure 6) built on a brick arcade, which is why the fountain was popularly known as Arcos Fountain. The fountain, built in soapstone, has the imperial crown and the date of 1833 on its top (GAIO SOBRINHO, 2006).

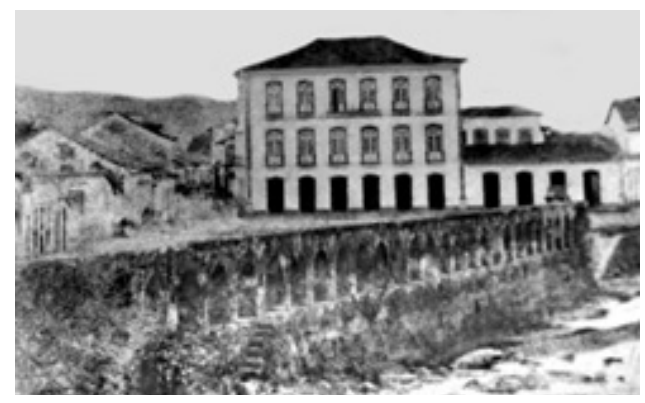

Figure 6. Aqueduct of the Legalidade Fountain at the Largo de Tamandaré. Source: IPHAN

\footnotetext{
(4) Place where all the gold collected in the region should be taken to collect "The Fifth" tax referring to the Portuguese Crown and for casting in gold bars (5) War of Canudos (1896 - 1897) - conflict of the population of the sertão of Bahia against Brazilian military, in the community of Canudos. The movement led by Antônio Conselheiro, was against social injustice. With the help of the federal government, the military massacred the entire population of Canudos and assassinated their leader.
} 
The aqueduct was demolished and the fountain dismantled in 1895 in Largo do Tamandaré by resolution of the City Council and proposal of the Public Works Commission. After this act, much regretted by the population, the parts of the fountain were assembled in different places but, in 1943, it was taken to the Expedicionários Square, where it is currently, but without watering (IPHAN, 2012).

The Monumento aos Expedicionários was built in honor of Brazilian soldiers killed in World War II and inaugurated on May 22, $1969^{(6)}$. The site is used for the commemorations of April 14, 1945, marking the most bloody battle of which the Brazilian Expeditionary Force participated, the Battle of Montese.

The monument is made of black granite, with a bronze soldier in the central part. Although the construction apparently does not demonstrate interaction with the style of the square, it justifies the current nomenclature of this space.
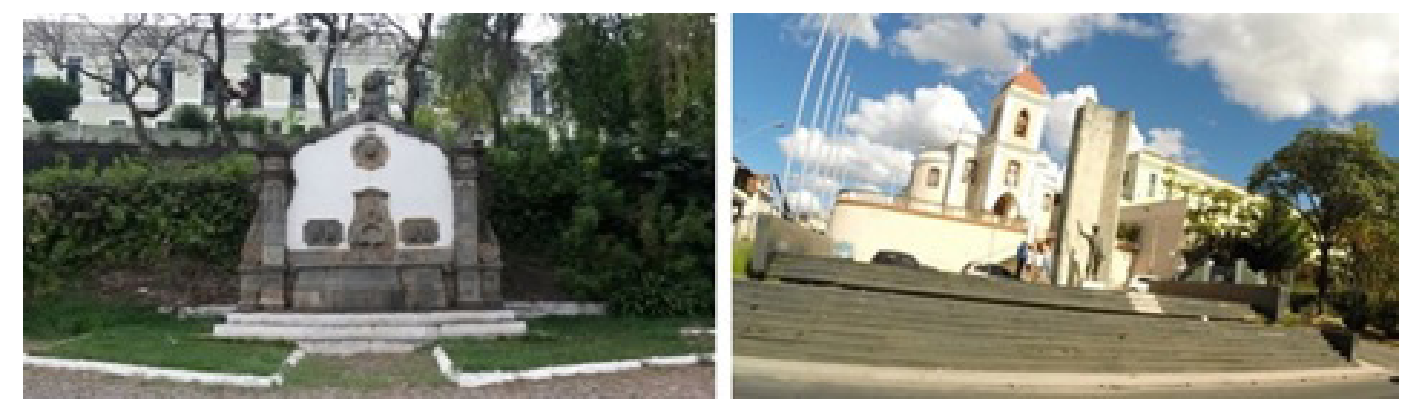

Figure 7. Left: "Legalidade” Fountain, Right: Expedicionários Monument.

\section{Square surroundings}

In Figure 8, it is possible to observe the square and its surroundings. To the left is the São Gonçalo Garcia Church, below the church the Expedicionários Monument and, above the square, the building that currently houses the Maria Teresa Municipal School.

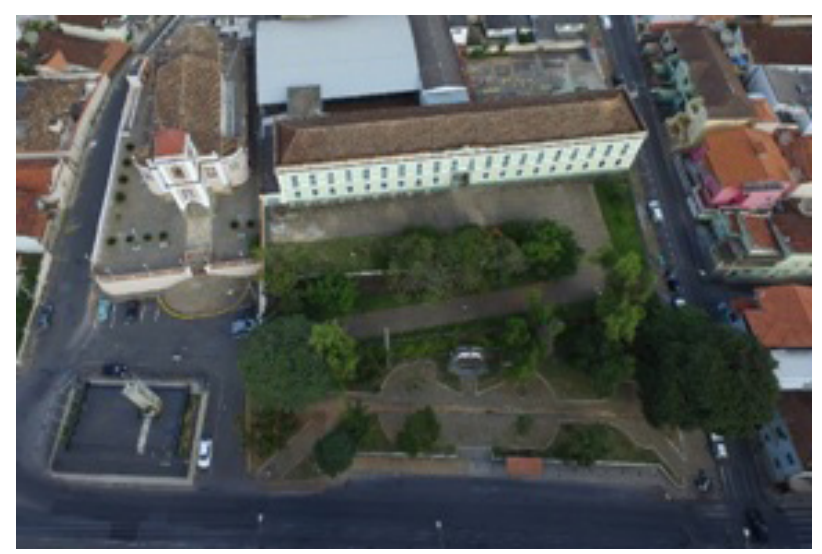

Figure 8. Expedicionários Square and its surroundings. Source: Aline Mundim (2017).

\section{The building}

Due to its privileged geographic location and the slave economy, the Intendência and Gold Casting House was installed in São João del-Rei, located on high ground, from where the whole village and beyond the valley were seen (SAINT-HILAIRE, 1941; GAIO SOBRINHO, 1996).

According to Luccock's (1975) traveler account:

The Gold Casting House was a solid and good building, beautifully situated on high ground. For there, all the gold found in the neighborhood must be taken, and I believe that in all the region, in order to merge it, paying the duties imposed, which amount to one-fifth of the gross weight. There also, all the operations of refining and emission of the bar with its respective certificate, are executed with the greater of the precisions and formalisms. The Gold Casting House of São João Del Rei also functioned as a kind of Bank for the whole Region.

With the decrease in gold collection, the Gold Casting House was closed in 1832. The building was then occupied by the Duval School. Later, from 1832 to 1920, the old 51st Battalion of Hunters operated in the building. On March

(6) Probably in commemoration of Victory Day, May, 8th, when the Nazi army surrendered, ending the Second World War. 
14, 1925, the second school group of São João del-Rei was created, receiving the denomination D. Maria Teresa School. In 1942, the school began to receive the typological denomination of Maria Teresa Municipal School (CINTRA, 1982, GAIO SOBRINHO, 2000).

\section{São Gonçalo Garcia Church}

On the right side of the square, there is the São Gonçalo Garcia Church, built by the São Gonçalo Garcia Brotherhood, in 1772. It was initially a very simple chapel without towers that, in the middle of the nineteenth century, was renovated and its work was completed in 1903, altering its original appearance (MONUMENTOS RELIGIOSOS, 2014).

The construction of this square is different from other historical Brazilian squares of that period, that originated in front or as part of a church. In this case, its construction is related to the building on the upper level of the square, which currently houses the Maria Teresa Municipal School, not to the existing church in its surroundings.

\section{The Square in the 21st Century}

In a photograph of 2017 (Figure 9), it is possible to observe that the square maintains the same format of 1930 , with trapezoidal beds in a single plateau. The square is accessed by the front stairs and side ramps. It has a varied paving; internally, it consists of irregular stones, hindering the traffic in the square and the walk that skirts the square is of Portuguese stones. In spite of the transformations that have taken place over the years, the square still conserves part of the route with paved paths, besides beds of understory, shrub and tree vegetation.

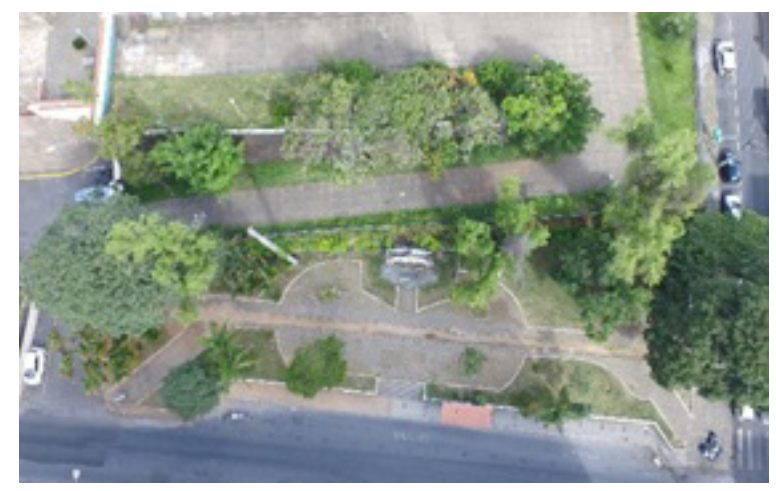

Figure 9. Expedicionários Square.

Source: Aline Mundim (2017).

The square has a great diversity of tree, shrub and forage species, but without an ordered planning. The wall dividing the square with the building on the upper level consists of fern (Nephrolepis sp.) and monster fruit (Monstera deliciosa). Implanted in the beds, without any organization or planning are: azalea (Rhododendron simsii), areca palm (Dypsis lutescens) cordyline (Cordyline terminalis), boxwood (Buxus sempervirens), black lapacho (Handroanthus heptaphyllus).

The square is currently frequented by residents living near the place; some use the space for leisure, others only use the place as a passage. Although it is a place that has many stories and shelter the Legalidade Fountain, the square is not valued for its historical-cultural and social aspects.

\section{CONCLUSIONS}

The Expedicionários Square has undergone many changes since its construction in the mid-1830s until the present day (2017). Throughout its history, its layout, uses and modifications were influenced by the diverse uses of the great building existing in its surroundings. Political facts were also of paramount importance for these modifications, highlighting the name changes.
The first major intervention was in 1930, with the renovation of the Batallion Garden that was transformed into a square, and several modifications were necessary. It passed from a place with grids and great diversity of ornamental species distributed in small beds, to an open place with less ornamental species in larger beds. In addition to the aesthetic change, the place underwent a change in population appropriation. Another great intervention that took place in the square was the transfer of the Legalidade Fountain to this place, which is currently a city landmark.

The square is currently very different from its initial project. The vegetation and furniture that make up the square are in poor condition. The site needs a revitalization project, which houses the valuation of a historical heritage, besides the residents' needs.

\section{ACKNOWLEDGEMENTS}

The authors would like to thank FAPEMIG (Fundação de Amparo à Pesquisa de Minas Gerais) for the financial support and CNPq (Conselho Nacional de Desenvolvimento Científico e Tecnológico) for the grants provided. 


\section{AUTHORS CONTRIBUTIONS}

A.S.M.: research and project execution, writing and correction of the manuscript. P.D.O.P.: idealization of the project, research execution, support and correction of the manuscript. R.B.S.: support in research and project execution. F.L.B.: support in research and project execution. S.F.N.S.C.A.: support and correction of the manuscript.

\section{REFERENCES}

ALVES, S.F.N.S.C.; PAIVA, P.D.O; GARCIA, C.S.G. Do Largo do Rossio ao Jardim: a gênese da Praça Gomes Freire em Mariana-MG. Ornamental Horticulture, v.22, n.3, p.350-360, 2016. DOI: <http://dx.doi.org/10.14295/ oh.v22i3.955>

ARTEN, F.A.C. Memória toponímica de Saint-Hilaire pelo caminho velho da Estrada Real. Letras \& Letras, v.26, n.1, 2010 .

BURTON, R.F. 1821-1890, Viagem do Rio de Janeiro a Morro Velho (tradução de David Jardim Júnior). Brasília: Senado Federal, Conselho Editorial, 2001. 530p. (Coleção O Brasil visto por estrangeiros).

CALAES, G.D.; OLIVEIRA, L.C. A Estrada Real e a transferência da corte portuguesa. In: A Estrada Real e a transferência da corte portuguesa: Programa Rumys Projeto Estrada Real. Rio de Janeiro: CETEM/MCT/ CNPq/CYTED, 2009. p.21-46.

CARTA DE JUIZ DE FORA. Carta dos jardins históricos brasileiros. Juiz de Fora: IPHAN, 2010. 16p.

CARVALHO, F.A. A Memória Toponímica dos Viajantes Naturalistas dos Séculos XVIII e XIX e a Estrada Real. Literatura em Debate, v.3, n.5, p.31-46, 2013.

CINTRA, S.O Efemérides de São João del-Rei. Belo Horizonte: Imprensa Oficial, 1982.

COSTA, A.G. Os Caminhos do Ouro e a Estrada Real. Lisboa - Belo Horizonte: Kapa Editorial e Editora UFMG, 2005. 244p.

DELPHIM, C.F.M. Intervenção em jardins históricos: manual. Brasília: IPHAN, 2005.
GAIO SOBRINHO, A. História da Educação em São João del-Rei. São João del-Rei: FUNREI, 2000.

GAIO SOBRINHO, A. Sanjoanidades: um passeio histórico e turístico por São João del-Rei. São João del-Rei: A Voz do Lenheiro, 1996.

GAIO SOBRINHO, A. São João Del Rei: 300 anos de histórias. São João Del Rei: Edição do autor, 2006.

GUIMARÃES, F.N. Ruas de São João del Rei. São João del Rei: FAPEC, 1994. 55p.

IPHAN-INSTITUTO DO PATRIMÔNIO HISTÓRICO E ARTÍSTICO NACIONAL. Superintendência do IPHAN. São João Del Rei, 2015. (Arquivos).

LASSUS, B. L'obligation de I'inventio: du paysage aux ambiances successives. In: BERQUE (Dir.). Cinq propositions pour unethéorie du paysage. Paris: Champ Vallon, 1994.

LUCCOCK, J. Séc. 19. Notas sobre o Rio de Janeiro e partes meridionais do Brasil (tradução do prof. Milton da Silva Rodrigues). Belo Horizonte: Ed. Itatiaia; São Paulo: Ed. da Universidade de São Paulo, 1975. (Reconquista do Brasil. v.21)

LUNGINBUHL, Y. Paysage et identification, qualification et objectifs de qualités. In: PAYSAGE et développement durable: les enjeux de la Convention européenne du paysage. Strasbourg: Conseil de l'Europe, 2006.

MALDOS, R. Formação urbana da cidade de São João del Rei. São João del Rei: [s.n.], 2000.

MARTINS, S; IGLÉSIAS, F; MAZZONI, S. Caminhos de Minas. São Paulo: Ed. Publicações e Comunicações, 1992.

MONUMENTOS RELIGIOSOS, 2014 Disponível em $<$ http://www.guiadelrei.com.br/turismo-sao-joao-del-rei/ monumentos-religiosos/> Acessed on 23 january 2016.

SAINT-HILAIRE, A. Viagem pelo distrito dos diamantes e litoral do Brasil; tradução de Leonam de Azeredo Pena. São Paulo: Companhia Editora Nacional, 1941.

SODRÉ, N W; SCHENDEL, M. Formação histórica do Brasil. Rio de Janeiro: Civilização Brasileira, 1979. 